\title{
Combination Effect of Cecendet (Physalisangulata L.) Extract and Methylprednisolone in Reducing Inflammation and Improving Renal Functions in Pristane-induced Lupus Rat Models
}

\author{
Shiane Hanako Sheba, ${ }^{1}$ Nur Asni Setiani, ${ }^{1}$ Afifah B. Sutjiatmo, ${ }^{2}$ Suci Nar Vikasari, ${ }^{2}$ Elin Yulinah Sukandar ${ }^{3}$ \\ ${ }^{1}$ Syamsi Dhuha Foundation,Indonesia, ${ }^{2}$ Faculty of Pharmacy Universitas Jenderal Achmad Yani, Cimahi, Indonesia \\ ${ }^{3}$ School of Pharmacy, Institut Teknologi Bandung, Indonesia
}

\begin{abstract}
Cecendet (Physalis angulata L.) is a herbal plant commonly used for traditional remedies in Indonesia to prevent inflammation in rheumatic disease. Several studies have determined that cecendet has an immunosuppressant activity towards pristane-induced lupus animal model. A preliminary study has proven that its use is safe in animals based on acute and sub-chronic toxicity tests. In management of lupus, methylprednisolone is used for primary immunosuppressant agent. This study aimed to investigate the effect of cecendet ethanolic extract in combination with methylprednisolone on inflammation, urinalysis, and serum creatinine level of rats as pristaneinduced lupus animal models. This study was conducted at the Pharmacology Laboratory of Pharmacy Faculty of Jenderal Ahmad Yani University in January 2016. Four groups of female rats were used i.e. normal group, control group, $62.5 \mathrm{mg} / \mathrm{kg}$ body weight (BW) cecendet ethanolic extract group, and group receiving $62.5 \mathrm{mg} / \mathrm{kg} \mathrm{bw}$ cecendet ethanolic extract combined with $0.36 \mathrm{mg} / \mathrm{kg}$ body weight methylprednisolone for six weeks, followed by thirty days of $0.5 \mathrm{~mL}$ pristine-induced. Examinations on anti-inflammation effect, urinalysis, and serum creatinine level were performed in week 3 and 6 during the intervention. The results showed that the administration of cecendet ethanolic extract alone and in combination with methylprednisolone could inhibit inflammation and reduce proteinuria and serum creatinine level when compared to the control group.
\end{abstract}

Key words: Anti-inflammation, cecendet, creatinine,methylprednisolone, Physalis angulata L.

\section{Pengaruh Pemberian Kombinasi Ekstrak Cecendet (Physalisangulata L.) dan Metilprednisolon terhadap Penurunan Radang Dan Perbaikan Fungsi Ginjal pada Model Tikus Lupus yang Diinduksi Pristana}

\begin{abstract}
Abstrak
Tanaman cecendet (Physalis angulata L.) sering digunakan sebagai obat tradisional di Indonesia, antara lain sebagai antiradang untuk mengobati reumatik. Penelitian terdahulu menunjukkan bahwa cecendet memiliki aktivitas imunosupresan pada hewan model lupus yang diinduksi pristana dan aman berdasar atas uji toksisitas akut dan subkronis. Pada penanganan lupus, metilprednisolon digunakan sebagai obat utama imunosupresan. Penelitian ini bertujuan menguji khasiat ekstrak etanol herba cecendet dalam penggunaan tunggal dan kombinasi dengan metilprednisolon terhadap radang, urinalisis, dan kadar kreatinin serum pada tikus yang diinduksi pristana sebagai model hewan lupus. Penelitian dilaksanakan di Laboratorium Farmakologi Fakultas Farmasi Universitas Jenderal Ahmad Yani pada bulan Januari 2016. Tikus betina sebagai hewan uji dibagi menjadi 4 grup, yaitu grup normal, grupkontrol, grup diberi sediaan ekstrak etanol herba cecendet $62,5 \mathrm{mg} / \mathrm{kgBB}$ tunggal, dan grup hewan uji diberi sediaan ekstrak etanol herba cecendet 62,5 mg/kgBB kombinasi dengan metilprednisolon $0,36 \mathrm{mg} / \mathrm{kgBB}$ selama enam minggu, setelah tiga puluh hari diinduksi $0,5 \mathrm{~mL}$ pristana. Tiga dan enam minggu setelah pemberian sediaan uji, dilakukan uji efek antiradang, pemeriksaan urin, dan pengukuran kadar kreatinin serum. Hasil penelitian menunjukkan bahwa pemberian ekstrak etanol herba cecendet tunggal maupun sebagai komplemen dengan metilprednisolon selama enam minggu memperlihatkan pengaruh penghambatan pembentukan radang, menurunkan proteinuria, dan menurunkan kadar kreatinin serum jika dibanding dengan kelompok kontrol.
\end{abstract}

Kata kunci: Anti-radang, Cecendet, kreatinin, metilprednisolon, Physalis angulata L.

Corresponding Author: Shiane Hanako Sheba, Research Division Syamsi Dhuha Foundation, Jalan Ir. H. Juanda No. 369 Komp DDK No.1 Bandung, West Java, Indonesia, Email: shianehanako2014@gmail.com 


\section{Introduction}

Systemic lupus erythematosus (SLE) is a chronic systemic autoimmune inflammatory disease which can affect many organs. The etiology of SLE is still unknown, but it may be caused by several factors such as genetic, hormonal, and environmental. Clinical manifestations of SLE are mostly found as malar rash, photosensitivity, arthritis, oral ulcers, and nephropathy. ${ }^{1}$

Pathogenesis of SLE has not been clearly studied. Clinical improvement of SLE can be classified into several steps, starting from predisposition to autoimmune problems, autoantibody formation, inflammation, and related organs until the clinical symptoms occur. Patients of SLE may have intermittent clinical symptoms leading to remission (disease activity) and organ disorders (disease damage) caused by chronic inflammation. ${ }^{2}$ One of diagnostic parameters used in Indonesia to observe SLE activity is Mexican SLE Disease Activity Index (MEXSLEDAI). ${ }^{3}$ There is still no suitable medication for SLE until today. However, the symptoms can be controlled so that continuous short- or longterm treatments should be given to the SLE patients.

The management of SLE is recommended to improve the patient's quality of life. The treatments of SLE particularly can lengthen remission, decrease disease activity, and maintain organs so that the patients can do daily activities optimally. ${ }^{4}$ Foundation of the SLE treatments includes education and counseling, rehabilitation program, and medical treatment. The medical treatment for SLE patients are non-steroidal anti-inflammatory drug (NSAID), anti-malaria (chloroquine), steroid, immunosuppressant or cytotoxic (azathioprine, cyclophosphamide, mycophenolate mofetil, methotrexate, cyclosporine A), and another therapy such as monoclonal antibody (rituximab, belimu-mab). ${ }^{3-6}$ Generally, methylprednisolone becomes the main therapy for SLE patients who have high, moderate, and low intensity of activities, or as a maintenance dose. ${ }^{3}$

Therapy supplement by consuming herbs can be an alternative for SLE treatment. In addition, herbs can regulate immune systems because of their function in prohibit disease activity. Standardized traditional herbs for SLE patients cultivated in Indonesia are interestingly used for alternative therapy which is considered affordable, widely available, and effective. Several studies have examined natural resources likeextract supplements that can regulate SLE disease activity. Physalis angulata Linn. (familia Solanaceae), known as cecendet, is a seasonal herb with several characteristics such as 0.1-1 $\mathrm{m}$ of height, upright, and with strong branch. In Java Island, Indonesia, it grows in low land area up to $1,200 \mathrm{~m}$ above the sea levels as commonly found as weeds in the fields, farming lands, bushes, or on the roads. Traditionally, it can be used for looseness, rheumatic, abscess, gums bleeding, stomachache, sprains, diabetes mellitus, epilepsy, worm, influenza, respiratory inflammation, testicular inflammation, diuretic, and jaundice.?

Withangulatin A (WA), is an isolated compound derived from Physalis angulata Linn. which has a high immunosuppresant activity, therefore, it can be used to control autoimmune disease ${ }^{5,6} \mathrm{WA}$ might reduce the accumulation of proteinuria symptoms and levels of anti-doublestranded DNA antibodies in animal model. Moreover in animal model, WA could improve renal histopathologic characteristics and reduced an expression of $B$ cell-activating factor (BAFF), BAFF-R and related gene in the spleen. These findings indicate that WA might have an immunospression effect via inhibiting BAFF signaling, which suggest a potential application in the treatment of SLE. ${ }^{5,6}$

Ethanolic extract of cecendet at a dose of 50 $\mathrm{mg} / \mathrm{kg}$ and $100 \mathrm{mg} / \mathrm{kg}$ is able to reduce urine protein level of pristane-induced animal models as dexametason effect; while ethanolic extract of cecendet at a dose of $1000 \mathrm{mg} / \mathrm{kg}$ has a potential effect as immunosuppressant. The extract works primarily on specific immune response by lowering immune response approaching normal condition, not by suppressing immune response as prednisone..$^{8-10}$ The animal models was induced by Pristane, an intraperitoneal hydrocarbon compound to induce lupus. The pristane can cause cell death through lymphoid cell apoptosis in the peritoneal cavity leading to autoimmune disease induction which is marked by the presence of positive antinuclear of antibody after a 4-week induction. ${ }^{8,9,11}$

Thepotential effect of cecendetasa supplement for SLE therapy is commonly associated with immunosuppressant as one of several standards for lupus therapies. Methylprednisolone is a main immunosuppressant used in particular dosages; high, moderate, and low as a treatment dosage. ${ }^{3}$ Since the usage of methylprednisolone in SLE patients cannot be stopped, the activity of methylprednisolone and cecendet ethanolic extract combination is required to be examined. . In the previous study, many herbs interact with 
drugs through a complex cytochrome P450 and/ or P-glycoprotein mechanism. Herb-induced enzyme inhibition and/or induction may result in enhanced and / or decreased plasma, tissue, urine and bile drug concentrations, leading to a change in a drug's pharmacokinetic parameters. ${ }^{12}$

This study observed the effects of ethanolic cecendet extract and methylprednisolone combination that function as anti-inflammation and improve renal functions in lupus rat models induced by pristane. This study aimed to become a benchmark for SLE patients who consume cecendet extract as a supplement $r$ that complement methylprednisolone as the main therapy.

\section{Methods}

Material used for this study is cecendet extract in amylum maydis (5:4 ratio). The extract was prepared by PT. Phytochemindo Reksa, a pharmaceutical manufacturing certified for good manufacturing practice for traditional medicine (Certificate Number: 0104/CPOTB/14.1/43/ VIII/2008) by National Agency for Drug dan Food Control of The Republic of Indonesia. - Methylprednisolone were obtained from marketplace as a generic brand of $4 \mathrm{mg}$ tablet. All the procedures were approved by The health research ethic committee Faculty of Medicine Universitas Padjadjaran Bandung with ethical approval no 262/UN6.C1.3.2/KEPK/PN/2061.

The animal models were female Wistar rats aged 3 months purchased from Animal Laboratory Life Science Center, Bandung Institute of Technology. The animals were admitted to have healthy condition if the examination result showed that there was no sign of hair fall. The rats were acclimatized during a week. Afterwards, the rats were intraperitoneally induced by 0.5 $\mathrm{mL}$ of pristane. The pristane is a hydrocarbon compound which can be given intraperitoneally to the lupus rat models. The pristane can cause cell death through lymphoid cell apoptosis in the peritoneal cavity leading to autoimmune disease induction, which is marked by the presence of positive antinuclear of antibody after a 4-week induction. ${ }^{8,10}$

The animal models were randomly divided into 4 groups (each group consisted of 5 rats): normal group, control group which was given Na CMC $2 \%$ of suspension; group of cecendet extract at the dose $62.5 \mathrm{mg} / \mathrm{kg}$ BW (daily and orally given); group of combination of cecendet extract at the dose $62.5 \mathrm{mg} / \mathrm{kg} \mathrm{BW}$ and methylprednisolone at the dose of $0.36 \mathrm{mg} /$ kg BW (daily and orally given with a 5-minute interval).

Four weeks after pristane induction, urinalysis and serum creatinine level were performed. Afterwards, the animals were given test preparation solution based on criteria of each group. Examinations relating to the effects of cecendet extract and combination of cecendet extract and methylprednisolone were conducted in week 3 and 6 during intervention (week 7 and 10 after pristane induction).

Anti-inflammation effect was observed by measuring animal foot edema using plethysmometer. Animal's left foot was marked and injected $0.05 \mathrm{~mL}$ suspension of carrageenan lambda 1\% intraplantar. Animal's left foot was measured before induction and 60,120,180, and 240 minutes after induction. The percentage of inflammation and inflammation inhibition were calculated by using the following formula:

$$
\% \text { inflammation }=\frac{\mathrm{V}_{\mathrm{t}}-\mathrm{V}_{0}}{\mathrm{~V}_{0}} \times 100 \%
$$

Note:

$\mathrm{V}_{0}=$ the rats' volume of sole of the foot before the carrageenan was induced

$\mathrm{V}_{\mathrm{t}}=$ the rats' volume of sole of the foot after the carrageenan was induced

Inflammation inhibition calculation:

$\%$ inhibition of inflammation $=\frac{\mathrm{A}-\mathrm{B}}{\mathrm{A}} \times 100 \%$

Note:

$A=$ average volume of sole of the footfound in control group

$\mathrm{B}=$ average volume of sole of the footfound intervention group

Serum creatinine level examination was performed by collecting blood veins from the tail of the rats and placed in eppendorf tube. The bloods were centrifuged $5000 \mathrm{rpm}$ during 6 minutes. Serum creatinine level was calculated using reagent (Dialabs $\AA$ ) by spectrophotometer with wavelength ranged $546 \mathrm{~nm}$.

Urinalysis was performed by collecting urine of the animal models in the metabolic cage during 24 hours, then the urine was centrifuged 5,000 rpm during 6 minutes. The parameters included volume, $\mathrm{pH}$, specific gravity, and protein level were calculated using reagent (Dialabs $®$ ) 
S. H. Sheba, et al: Combination Effect of Cecendet (Physalisangulata L.) Extract and Methylprednisolone in Reducing Inflammation and Improving Renal Functions in Pristane-induced Lupus Rat Models

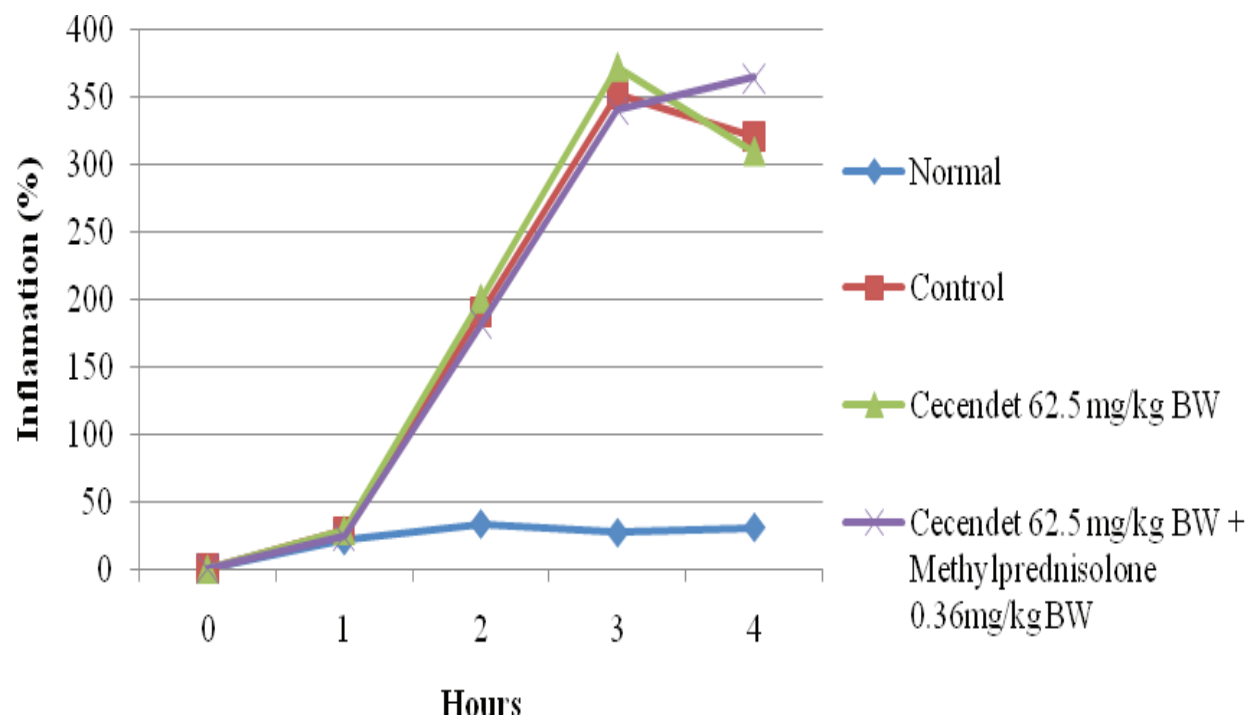

Figure 1 Anti-inflammation Effect after 3 Weeks of Intervention

by spectrophotometer with wave length ranged $410 \mathrm{~nm}$.

\section{Results}

Figure 1 showed the anti-inflammation effect of cecendet extract and its combination with methylprednisolone on paw rat after 3 weeks of administration. There was no statistical difference in edema among all groups during 4-hour observation of anti-inflammation test.
The anti-inflamation effect of cecendet extract and combination of cecendet extract and methylprednisolone were shown after 6-week administration (Fig 2). Combination of cecendet extract and methylprednisolone showed the lowest differences of feet edema in 2 hours of the test, indicating less edema than other groups.

Table 1 shows the inflammation inhibition results comparison between cecendet extract and combination of cecendet extract and methylprednisolone. Based on the inhibition of inflammation rate in both groups, the

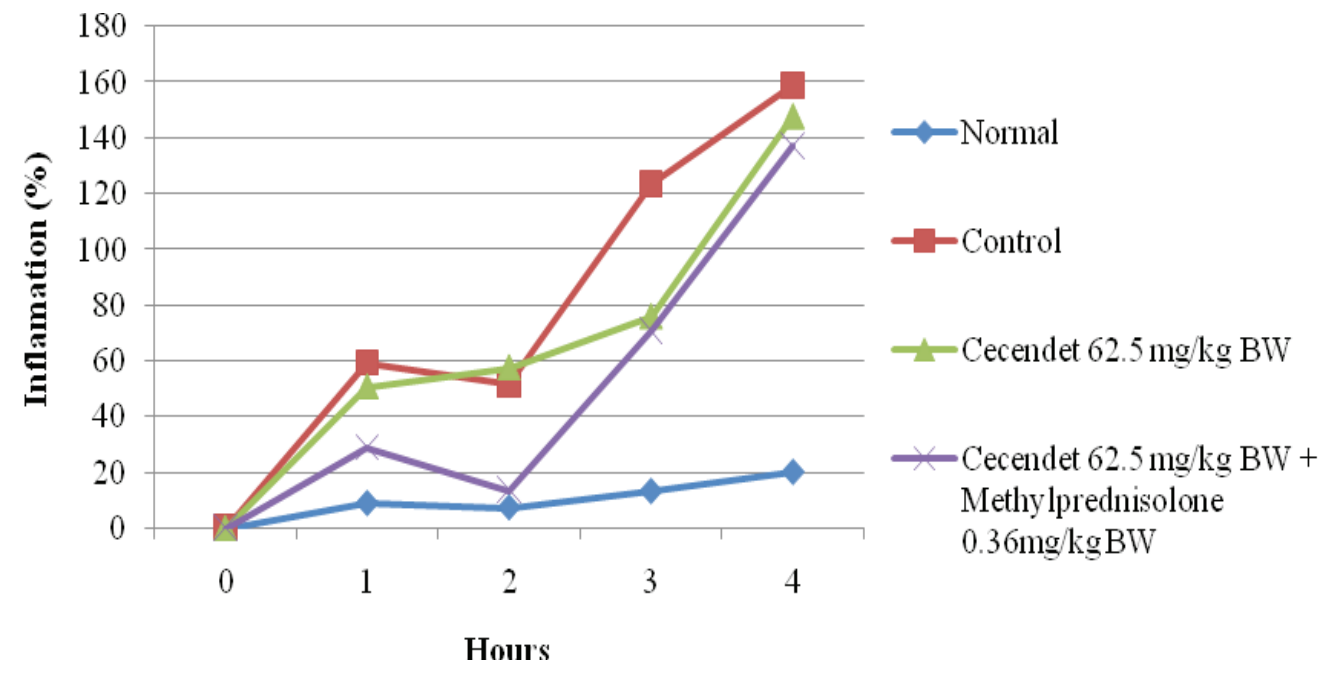

Figure 2 Anti-inflammation Effect after 6 Weeks of Intervention 
Table 1 Inflammation Inhibition Percentage

\begin{tabular}{|c|c|c|c|c|c|}
\hline \multirow{2}{*}{ Group } & \multicolumn{4}{|c|}{ Interval Period (Hour) } & \multirow{2}{*}{$\begin{array}{c}\text { Inhibition of } \\
\text { Inflammation in } \\
\text { Total (\%) }\end{array}$} \\
\hline & 1 & 2 & 3 & 4 & \\
\hline \multicolumn{6}{|l|}{3 week intervention } \\
\hline Cecendet extract & -1.73 & -5.38 & -5.68 & 3.22 & -9.57 \\
\hline $\begin{array}{l}\text { Cecendet extract+ } \\
\text { methylprednisolone }\end{array}$ & 15.72 & 4.30 & 3.37 & -13.81 & 9.58 \\
\hline \multicolumn{6}{|l|}{6 week intervention } \\
\hline Cecendet extract & 14.45 & -11.51 & 38.53 & 7.05 & 48.52 \\
\hline $\begin{array}{l}\text { Cecendet extract+ } \\
\text { methylprednisolone }\end{array}$ & 51.34 & 73.19 & 42.68 & 13.75 & 180.96 \\
\hline
\end{tabular}

inflammation inhibition maximally occurred in 3 hours which was found after 6 weeks of postadministration preparation (Table 1).

Comparison of inflammation inhibition percentage in week 3 and 6 after intervention shows that cecendet extract could inhibit inflammation 5 times in week 6 compared to in week 3. Meanwhile, the effectiveness of the combination of cecendet extract and methylprednisolone is $19.5 \mathrm{x}$ greater in week 6 compared to in week 3 after intervention.

The administration of cecendet extract and the combination of cecendet extract and methylprednisolone in week 6 could reduce the serum creatinine level and was significantly different compared to the control group (Table 2).

Table 3 shows urinalysis result of all groups after 6 weeks of intervention. Proteinuria result revealed that the administration of cecendet extract and the combination of cecendet extract and methylprednisolone after 6 weeks could prohibit the increase of proteinuria in animal models. There was a significant difference of proteinuria result compared to the control group $(\mathrm{p}<0.05)$. Urine parameter improvement was supported by the urinary specific gravity after the administration of cecendet extract and the combination of cecendet extract and methylprednisolone during 6 weeks. Decreased urinary specific gravity was significantly different compared to the control group ( $\mathrm{p}<0.05)$.

\section{Discussion}

Cecendet herb is a natural resource which potentially can reduce SLE symptoms. Previous

Table 2 Serum Creatinine Level on 6 Weeks after Intervention

\begin{tabular}{lcccc}
\hline \multirow{2}{*}{$\begin{array}{c}\text { Examination } \\
\text { Period }\end{array}$} & Normal & Control & Cecendet extract & $\begin{array}{c}\text { Cecendet extract + } \\
\text { Methylprednisolone }\end{array}$ \\
\cline { 2 - 5 } Before induction & $0.33 \pm 0.16$ & $0.26 \pm 0.09$ & $\begin{array}{c}0.21 \pm 0.14 \\
(\mathrm{p}=0.507)\end{array}$ & $\begin{array}{r}0.22 \pm 0.08 \\
(\mathrm{p}=0.460)\end{array}$ \\
& & & $0.59 \pm 0.20$ & $0.44 \pm 0.11$ \\
After induction & $0.44 \pm 0.16$ & $0.48 \pm 0.17$ & $\begin{array}{c}(\mathrm{p}=0.361) \\
(\mathrm{p}=0.719)\end{array}$ \\
Week 3 & & $1.03 \pm 0.17$ & $1.01 \pm 0.11$ \\
Week 6 & $0.53 \pm 0.27$ & $1.03 \pm 0.08$ & $\begin{array}{c}(\mathrm{p}=0.963) \\
(\mathrm{p}=0.727)\end{array}$ \\
\hline
\end{tabular}

Note: $\mathrm{n}=5 ;{ }^{*} \mathrm{p}<0.05$.compared to control group by using Student $\mathrm{t}$ test 
S. H. Sheba, et al: Combination Effect of Cecendet (Physalisangulata L.) Extract and Methylprednisolone in Reducing Inflammation and Improving Renal Functions in Pristane-induced Lupus Rat Models

Table 3 Urinalysis on 6 Weeks after Intervention

\begin{tabular}{|c|c|c|c|c|}
\hline \multirow{2}{*}{ Observation Period } & \multicolumn{4}{|c|}{ Urine Analysis between the Groups } \\
\hline & Normal & Control & Cecendet Extract & $\begin{array}{c}\text { Cecendet Extract + } \\
\text { Methylprednisolone }\end{array}$ \\
\hline \multicolumn{5}{|l|}{ Volume (mL) } \\
\hline Before induction & $3.14 \pm 1.66$ & $8.70 \pm 3.70$ & $4.80 \pm 3.27(p=0.115)$ & $5.40 \pm 3.05(p=0.162)$ \\
\hline After induction & $17.40 \pm 14.96$ & $7.20 \pm 5.76$ & $6.80 \pm 5.76(p=0.915)$ & $3.20 \pm 1.30(p=0.168)$ \\
\hline 3Weeks & $10.64 \pm 3.86$ & $7.78 \pm 2.13$ & $8.00 \pm 3.16(p=0.901)$ & $6.68 \pm 2.09(p=0.434)$ \\
\hline 6 Weeks & $11.52 \pm 2.07$ & $8.44 \pm 0.38$ & $6.28 \pm 3.34(p=0.189)$ & $8.24 \pm 0.85(p=0.646)$ \\
\hline \multicolumn{5}{|l|}{$\begin{array}{l}\text { Specific gravity (g/ } \\
\text { mL) }\end{array}$} \\
\hline Before induction & $1.25 \pm 0.10$ & $1.25 \pm 0.08$ & $1.25 \pm 0.02(\mathrm{p}=0.961)$ & $1.20 \pm 0.05(\mathrm{p}=0.304)$ \\
\hline After induction & $1.01 \pm 0.15$ & $1.35 \pm 0.24$ & $1.42 \pm 0.44(\mathrm{p}=0.783)$ & $1.25 \pm 0.08(\mathrm{p}=0.375)$ \\
\hline 3Weeks & $1.03 \pm 0.14$ & $1.16 \pm 0.04$ & $1.04 \pm 0.07(\mathrm{p}=0.010)^{*}$ & $1.02 \pm 0.15(\mathrm{p}=0.082)$ \\
\hline 6 Weeks & $1.03 \pm 0.03$ & $1.18 \pm 0.11$ & $1.06 \pm 0.03(\mathrm{p}=0.043)^{*}$ & $1.04 \pm 0.08(\mathrm{p}=0.042)^{*}$ \\
\hline \multicolumn{5}{|l|}{ pH } \\
\hline Before induction & $6.60 \pm 0.55$ & $7.40 \pm 0.55$ & $7.60 \pm 0.55(p=0.580)$ & $7.80 \pm 0.45(\mathrm{p}=0.262)$ \\
\hline After induction & $7.60 \pm 0.55$ & $8.00 \pm 0.71$ & $8.20 \pm 0.45(p=0.608)$ & $8.80 \pm 0.45(\mathrm{p}=0.065)$ \\
\hline 3Weeks & $7.00 \pm 0.71$ & $7.80 \pm 0.45$ & $7.60 \pm 0.55(p=0.545)$ & $7.80 \pm 0.45(\mathrm{p}=1.000)$ \\
\hline 6 Weeks & $7.60 \pm 0.55$ & $8.00 \pm 0.00$ & $8.00 \pm 0.00(p=1.000)$ & $8.00 \pm 0.00(\mathrm{p}=1.000)$ \\
\hline \multicolumn{5}{|l|}{ Protein (mg) } \\
\hline Before induction & $0.35 \pm 0.19$ & $0.35 \pm 0.11$ & $0.31 \pm 0.28(\mathrm{p}=0.761)$ & $0.45 \pm 0.23(\mathrm{p}=0.400)$ \\
\hline After induction & $0.51 \pm 0.16$ & $0.66 \pm 0.44$ & $0.87 \pm 0.60(\mathrm{p}=0.553)$ & $0.64 \pm 0.13(p=0.910)$ \\
\hline 3Weeks & $0.15 \pm 0.05$ & $0.49 \pm 0.23$ & $0.26 \pm 0.13(\mathrm{p}=0.095)$ & $0.30 \pm 0.07(\mathrm{p}=0.116)$ \\
\hline 6 Weeks & $0.23 \pm 0.08$ & $1.00 \pm 0.09$ & $0.49 \pm 0.28(\mathrm{p}=0.005)^{*}$ & $0.41 \pm 0.13(\mathrm{p}=0.001)^{*}$ \\
\hline
\end{tabular}

Note: $\mathrm{n}=5$; ${ }^{*} \mathrm{p}<0.05$.compared to control group by using Student $\mathrm{t}$ test

studies relating to the effects of cecendet herb stated that it is beneficial for anti-inflammation, immunomodulator, immunosuppressant, and cytotoxic. ${ }^{5,8,9}$

In this study, the combination of cecendet extract and methylprednisolone can reduce inflammation compared to cecendet extract in 6 weeks of intervention. Measurement of inflammation inhibition in the combination of cecendet extract and methylprednisolone group described that effectiveness improved 19.5 times in week 6 compared to in week 3 . This finding shows that long-term administration of cecendet extract and the combination of cecendet extract and methylprednisolone can reduce inflammation.

The previous study proved that the effectiveness of cecendet extract at a dose of $1,000 \mathrm{mg} / \mathrm{kg}$ can be used as anti-inflammation in lupus rat models. It has an immediate reaction when compared to prednisone which shows significant effects on day $7 .{ }^{8} \mathrm{~A}$ different period of the effects may be caused by different dosage. The effects of cecendet extract should be further analyzed in order to obtain the proper results.

Decreased renal functions in lupus nephritis are characterized by higher level of serum creatinine and several changes after performing urine tests, such as proteinuria, urine volume, and urinary specific gravity. ${ }^{13,14}$ Results in this study conveyed that serum creatinine level of cecendet extract group and the combination of cecendet extract and methylprednisolone group were lower $(p<0.05)$ compared to the control group in week 6 during the intervention. The urine $\mathrm{pH}$ was not different from the control group, but the proteinuria level and urinary specific gravity was lower than the control group $(p<0.05)$. The results illustrated that the effectiveness of cecendet extract and the combination of cecendet extract and methylprednisolone in repairing renal functions did not show a significant 
difference. Both cecendet extract and combination of cecendet extract and methylprednisolone could reduce serum creatinine level, urinary specific gravity, and urine protein which were different from the results in the control group. A previous study reported that ethanolic extract of cecendetat at a dose of $750 \mathrm{mg} / \mathrm{kg} \mathrm{BW}$ can reduce serum creatinine level on day 7 while histopathological analysis on renal at a dose of $1,500 \mathrm{mg} / \mathrm{kg}$ BW showed that improvement of disrupted glomerular cells and widened urinarius can occur, and decreased epithelial cells come into the tubular lumen. ${ }^{15}$

Administration of cecendet extract at a lower dose such as $50 \mathrm{mg} / \mathrm{kg}$ BW determined that the effect of cecendet ethanolic extract on week 7 could reduce proteinuria level when compared to the control group $(\mathrm{p}<0.1)$ and it was at the same level as a the comparison of cyclophosphamide $(\mathrm{p}>0.1){ }^{10}$

Interval period should be considered while giving a combination of cecendet extract and methylprednisolone of each composition. In a previous study, a 30 minute interval period was considered insufficient because any interaction may occur, hence, the administration should be separately given minimum 2 hours of interval period. It can be applied so that the antiinflammation effect can work maximally. ${ }^{16}$

Combination of cecendet extract and methylprednisolone showed a significantantiinflammation effect when compared to cecendet extract alone. Both cecendet extract and its combination with methylprednisolone can reduce the levels of serum creatinine and urine protein when compared to the control group. The study findings are in line with the theory of an effect of Withangulatin $\mathrm{A}$, as bioactive isolated from cecendet, that has an immunosupresive effect by reducing proteinurine symptom and improve renal histopathologic characteristic. 5,6

Based on the result above, it can be concluded that cecendet extract shows potential effects for SLE medications and the effects can be enhanced if the cecendet extract is complemented to methylprednisolone.

\section{Acknowledgment}

This study was supported by Grants-in-Aid from Syamsi Dhuha Foundation; we thank Faculty of Pharmacy Jendral Ahmad Yani University and School of Pharmacy Bandung Institute of Technology for providing facilities during the study.

\section{References}

1. Hahn BH. The Pathogenesis of SLE. In: Wallace DJ, Hahn BH, editors. Dubois, lupus erythematosus and related syndrome. $8^{\text {th }}$ Ed. Philadelphia: Elsevier Saunders; 2013. p. 25-34.

2. Tsokos GC. Mechanisms of disease systemic lupus erythematosus. $\mathrm{N}$ Engl J Med. 2011;365:2110-21.

3. Rekomendasi perhimpunan reumatologi Indonesia untuk diagnosis dan pengelolaan lupus eritematosus sistemik. Jakarta: Perhimpunan Reumatologi Indonesia; 2011.

4. Galarza-Maldonado C, Kourilovitch MR, Molineros JE, Cardiel MH, Zurita L, Soroka $\mathrm{NF}$, dkk. The administration of low dose of rituximab followed by hydroxychloroquine, prednisone and low dose of mycophenolate mofetil is an effective therapy in Latin American patients with active systemic lupus erythematosus. Autoimmun Rev. 2010;10:108-11.

5. Sun L, Zhou L, Chen M, Zhong R, Liu J. Amelioration of systemic lupus erythematosus by Withangulatin A in MRL/ lpr mice. J Cell Biochem. 2011;112(9):237682.

6. Sun L, Liu J, Liu P, Yu Y, Ma L, Hu L. Immunosuppression effect of Withangulatin A from Physalis angulata via heme oxygenase 1-dependent pathways. Process Biochem 2011;46(2):482-8.

7. Chaidir L, Epi, Taofik A. Eksplorasi, Identifikasi, dan perbanyakan tanaman Ciplukan (Physalis angulata) dengan menggunakan metode generatif dan vegetatif. J Ilmu Pertanian. 2015;9(1):82-90.

8. Adnyana IK, Sukandar EY, Maestuti N, Setiawan F. Evaluation of ethanolic extracts of mullaca (Physalis angulata L.) herbs for treatment of lupus disease in mice induced pristane. J Procedia Chemistry. 2014;13:18693.

9. Djajanegara I, Wahyudi P. Sitotoksisitas ekstrak etanol herba ceplukan (Physalis angulata Linn.) terhadap Sel T47D secara in vitro. I Ilmu Kefarmasian Indonesia 2010;8(1):41-7.

10. Vikasari SN, Sutjiatmo AB, Sukandar EY, Suryani S, Perdana PA. Efek ekstrak etanol herba cecendet (Physalis angulata l.) pada kadar proteinuria hewan model Lupus Eritematosus Sistemik. Kartika: Jurnal Ilmiah Farmasi 2014;2(1):15-9.

11. Calvani N, Caricchio R, Tucci M, Sobel ES, 
S. H. Sheba, et al: Combination Effect of Cecendet (Physalisangulata L.) Extract and Methylprednisolone in Reducing Inflammation and Improving Renal Functions in Pristane-induced Lupus Rat Models

Silvestris F, Tartaglia P, et al. Induction of apoptosis by the hydrocarbon oil pristane: implications for pristane-induced lupus. J Immunol. 2005;175(7):4777-82.

12. Li B, Zhao B, Liu Y, Tang M, Lüe B, Luo Z, et al. Herb-drug enzyme-mediated interactions and the associated experimental methods: a review. J Tradit Chin Med. 2016;36(3):392408.

13. Seavey MM, Lu LD, Stump KL. Animal Models of systemic lupus erythematosus (SLE) and ex vivo assay design for drug discovery. Wiley Online Library: Current protocols in Pharmacology. Curr Protocols in Pharmacol. 2011;53(1) https://doi. org/10.1002/0471141755.ph0560s53

14. Gowda S, Desai PB, Kulkarni SS, Hull VV, Math AA, Vernekar SN. Markers of renal function tests. N Am J Med Sci. 2010;2(4):170-3.

15. Oktavia S, Dharma S, Yarman A. Pengaruh pemberian ekstrak etanol herba ceplukan (physalis angulata l.) terhadap gangguan fungsi ginjal mencit putih jantan. Jurnal Farmasi Higea. 2016;8(1):39-43.

16. Bushra R, Aslam N, Khan AY. Food-drug interactions. Oman Med J. 2011;26(2):7783. 